\title{
Estimation of In-vitro Plasma Protein Binding of Ampicillin in Horses Based on Spectrophotometric Method
}

\author{
Kondampati Kasturi Devi", Milindmitra Lonare, Saloni Singla, Suresh Kumar Sharma, \\ Vinod Kumar Dumka and Simrat Pal Singh Saini \\ Department Veterinary Pharmacology \& Toxicology, College of Veterinary Science, Guru Angad Dev Veterinary and Animal \\ Science University, Ludhiana, Punjab, INDIA \\ "Corresponding author: KK Devi; E-mail: kasturi120@gmail.com
}

Received: 09 Jan., 2020

Revised: 26 May, 2020

Accepted: 28 May, 2020

\begin{abstract}
Estimation of plasma protein binding (PPB) is of paramount importance in the pharmacokinetics characterization of drugs, as it can cause significant change in volume of distribution, clearance and half-life of the drug. Ampicillin ( $\alpha$-amino benzyl penicillin) is most commonly used drug in equine practice. This study was conducted to determine the extent of PPB of ampicillin in apparently healthy horses $(n=6)$. A simple spectrophotometric method was applied for the determination of ampicillin at 320 $\mathrm{nm}$ wavelength, based on acid degradation product of penicillin at $75^{\circ} \mathrm{C}$ in presence of citrate buffer $(\mathrm{pH}$ 5.2) and traces of copper salt. In the study, it was observed that this method permits the detection of ampicillin to a level not beyond $1.0 \mu \mathrm{g} / \mathrm{ml}$. Various concentrations of ampicillin $(3.125,6.25,12.5,25,50,100 \mu \mathrm{g} / \mathrm{ml})$ were prepared in triplicate in pooled plasma collected from healthy animals. In vitro binding of ampicillin to plasma proteins was determined by employing the equilibrium dialysis technique. The study revealed that the plasma protein binding of ampicillin was to the extent of $12.8 \pm 0.07 \%$. Binding capacity of ampicillin to plasma protein $\left(\beta_{\mathrm{i}}\right)$ and dissociation rate constant of protein-drug complex $\left(\mathrm{K}_{\beta}\right)$ in the present study were $0.34 \times$ $10^{-6} \pm 0.02 \times 10^{-6} \mathrm{~mol} . \mathrm{gm}^{-1}$ and $0.003 \times 10^{-9} \pm 0.0003 \times 10^{-9} \mathrm{~mol}$, respectively in horses. Hence, the study concluded that usage of spectrophotometric method helps in quick, cost effective and efficient results in estimation of PPB for ampicillin.
\end{abstract}

Keywords: Ampicillin, plasma protein binding, spectrophotometric method, horse

Since discovery, penicillin have been very effective against gram positive bacteria. Attempts to extend the antimicrobial activity of penicillin $\mathrm{G}$ had led to the development of semi-synthetic ampicillin in the year 1961 which is effective against gram positive and gram negative organisms (William and Petri, 2011). Ampicillin is effectively being employed against major clinical pathogenic organisms that are involved in equine infections (Meijer et al., 2000). Ampicillin is active against Staphylococcus aureus, Streptococcus pyogenes, Streptococcus viridans and Streptococcus pneumoniae, Gonococci, Neisseria meningitidis and Hemophilus influenzae (Greenwood, 2008). Plasma protein binding plays vital role in antimicrobial therapy as it influences pharmacokinetic and pharmacodynamic activity of a drug. Binding of penicillin with plasma proteins enhances their biological half-life through prevention of $\beta$-lactam ring hydrolysis as well as decreased renal elimination (Hornish and Kotarski, 2002). Protein bound fraction of the drug does not have any antibacterial activity; it is only unbound drug that possesses this activity (Craig and Kunin, 1976) and so, for evaluation of the potential efficacy of antibacterial, its plasma protein binding should be known.

Several methods have been published for the determination of ampicillin in pure form or pharmaceutical formulations as well as in biological samples included by spectrophotometric methods (Askal et al., 1991; Sastry et al., 1998) HPLC method (Burns et al., 1991) post-

How to cite this article: Devi, K.K., Lonare, M., Singla, S., Sharma, S.K., Dumka, V.K. and Saini, S.P.S. (2020). Estimation of in-vitro plasma protein binding of ampicillin in horses based on spectrophotometric method. $J$. Anim. Res., 10(3): 353-357.

Source of Support: None; Conflict of Interest: None क् क्ष 
column degradation method (Haginaka et al., 1987). The spectrophotometric method selected in the present study was that originally described by Smith et al. (1967) for determination of ampicillin, based on copper facilitated formation of stable acid degradation product which shows maximum absorption at $320 \mathrm{~nm}$. This paper describes the suitability of this assay for determination of ampicillin in pharmaceutical formulations as well as in plasma samples by UV-Visible spectrophotometer.

\section{MATERIALS AND METHODS}

\section{Reagents}

Analytical grade copper sulphate, citric acid, disodium hydrogen phosphate, potassium-dihydrogen phosphate were purchased from Merck (Germany). Analytical standard of ampicillin, dialysis tubing cellulose membrane was procured from Sigma Aldrich Co, USA.

Copper sulphate solution: Copper sulphate pentahydrate of $3.93 \mathrm{~g}$ was dissolved in 1 litre water.

Buffer solution pH 5.2: $0.1 \mathrm{M}$ citric acid solution of 464 $\mathrm{ml}$ was mixed with $0.2 \mathrm{M}$ disodium hydrogen phosphate solution of $536 \mathrm{ml}$. Adjust the $\mathrm{pH}$, if necessary, to $5.2 \pm 0.05$ with the citric acid or disodium hydrogen phosphate solution. To $15 \mathrm{ml}$ of the copper sulphate solution add the buffer at $\mathrm{pH} 5.2$ to a volume of 1 litre. $(1 \mathrm{ml}$ of this solution contains $15 \mu \mathrm{g}$ of copper).

\section{Experimental animals}

The study was conducted on clinically presented horses of age group 8-12 years of age with $385-480 \mathrm{~kg}$ body weights. Animals were monitored during the collection of blood samples. The protocol of the study was approved by the Committee for the Purpose of Control and Supervision of Experiments on Animals (Order No. F.No.25/4/2019CPCSEA, dt: 20/03/2019).

\section{Collection of blood samples}

Blood samples were collected into heparinised vials from jugular veins. Plasma was separated by centrifugation at $3000 \mathrm{rpm}$ for 15 minutes and stored at $-20^{\circ} \mathrm{C}$ till analysis further.

\section{In vitro plasma protein binding}

In vitro binding of ampicillin to plasma proteins was determined by employing the equilibrium dialysis technique (Gupta et al., 2006; Singh et al., 2019). The dialyzing bags ( $4 \AA$ pore size), $10 \mathrm{~cm}$ long were washed in running tap water and soaked overnight in phosphate buffer. Ampicillin concentrations (3.125, 6.25, 12.5, 25, $50,100 \mu \mathrm{g} / \mathrm{ml}$ ) were prepared in pooled plasma separated from blood taken from apparently healthy horses. Each dialyzing bag was knotted at one end before filling $5 \mathrm{ml}$ of plasma containing known amount of drug and the other end was then securely tied. Each bag was immersed in separate tubes containing $5 \mathrm{ml}$ of phosphate buffer $(0.2 \mathrm{M}$; pH 7.4; disodium hydrogen phosphate $11.3 \mathrm{~g}$, potassiumdihydrogen phosphate $2.7 \mathrm{~g}$, added to $1000 \mathrm{ml}$ of distilled water) and the tubes were incubated at $37^{\circ} \mathrm{C}$ for $24 \mathrm{~h}$ with intermittent shaking. At the end of incubation period phosphate buffers as well as contents of the dialyzing bags were separately analysed for the concentration of ampicillin by spectrophotometric assay in triplicate. The extent of in vitro plasma protein binding of ampicillin was calculated by the following equation.

Percent of drug bound to plasma protein $=\frac{C P^{\prime}-C B}{C P} \times 100$ where,

$$
\begin{aligned}
& C P^{\prime}=\text { Concentration of drug in plasma after incubation } \\
& C B=\text { Concentration of drug in buffer after incubation } \\
& C P=\text { Concentration of drug in plasma before incubation }
\end{aligned}
$$

Binding capacity of the plasma protein to ampicillin $\left(b_{i}\right)$ and the dissociation rate constant of protein drug complex $\left(\mathrm{K}_{\mathrm{b}}\right)$ were calculated by the method of Pilloud (1973).

\section{Apparatus}

Ultraviolet-Visible-Spectrophotometer $\quad$ Eppendorf $^{\mathrm{TM}}$, USA) with $1 \mathrm{~cm}$ matched quartz cells was used for all spectral measurements. $\mathrm{pH}$ meter (Thermo scientific ${ }^{\circledR}$ Digital pH Meter Orion star A111), electronic weighing balance (A\&D Instruments, India Pvt. Ltd.), refrigerated centrifuge (Eppendorf ${ }^{\mathrm{TM}}$, USA), hot water bath incubator shaker (Narang Scientific Works Pvt. Ltd), thoroughly clean and dried glasswares were used in the present study such as measuring cylinders, volumetric flasks and beakers 
were procured from Borosil Glass Works Ltd. (India). The glass wares were washed with hot water and detergent, rinsed with distilled water and finally dried in an oven prior to use.

\section{Spectrophotometric method for ampicillin detection}

\section{Preparation of standards}

Stock solution of $100 \mu \mathrm{g} / \mathrm{ml}$ ampicillin was prepared in distilled water. The standard solutions were prepared by dilution of stock solution with distilled water in a concentration range of $0.5,1,2,4,6,8$ and $10 \mu \mathrm{g} / \mathrm{ml}$. The stock solution containing glass vials were wrapped in aluminium foil and stored under deep refrigeration $\left(-20^{\circ} \mathrm{C}\right)$ until use.

\section{Calibration curve for ampicillin standards}

Buffered standard solutions of ampicillin at a range of concentrations $0.5,1,2,4,6,8$ and $10 \mu \mathrm{g} / \mathrm{ml}$ were assayed by the specified procedure.

\section{Spectrophotometric assay}

A simple and specific spectrophotometric method given by Smith et al. (1967) was applied for the determination of ampicillin at $320 \mathrm{~nm}$, based on acid degradation product of penicillin at $75^{\circ} \mathrm{C}$ in the presence of citrate buffer ( $\mathrm{pH}$ 5.2) and traces of copper salt. In the study, it was observed that this method has limitation, and the detection of ampicillin not beyond $1.0 \mu \mathrm{g} / \mathrm{ml}$. We have now extended the method to the assay of ampicillin in horse plasma for in-vitro plasma protein binding assay.

\section{Method validation}

The method was validated for linearity, precision (interday and intra-day), selectivity and sensitivity according to the ICH guidelines. Linearity could be established with standard plots constructed for ampicillin in the range of 1-10 $\mu \mathrm{g} \cdot \mathrm{ml}^{-1}$ (Table 1). The experiment was repeated thrice on the same day and additionally on two consecutive days to determine intra-day and inter-day precision, respectively. Calibration curve was plotted between ampicillin concentrations against absorbance readings as shown in Fig. 1.

\section{Plasma sample extraction procedure}

Plasma $(0.2 \mathrm{ml})$ from heparinized blood is taken in a $1.5 \mathrm{ml}$ centrifuge tube containing absolute ethanol $(0.4 \mathrm{ml})$. After mixing in vortex for few seconds and centrifuging for 5 min at 4500 RPM, clear supernatant $(0.2 \mathrm{ml})$ was taken into a $5 \mathrm{ml}$ tube with citrate buffer solution $(0.8 \mathrm{ml}$; $\mathrm{pH}$ 5.2) containing copper $(15 \mu \mathrm{g} / \mathrm{ml})$. The tube was agitated at $120 \mathrm{strokes} / \mathrm{min}$, incubated at $75^{\circ} \mathrm{C}$ for $30 \mathrm{~min}$ and then cooled in ice. The sample is taken in a $1.5 \mathrm{ml}$ cuvette and read at $320 \mathrm{~nm}$ wavelength against the blank given by the residual non-incubated fraction of the supernatant.

Table 1: Linearity data for ampicillin spiked in horse plasma $(\mathrm{n}=3)$

\begin{tabular}{llll}
\hline \multirow{2}{*}{ Drug } & \multirow{2}{*}{ Range } & \multicolumn{2}{c}{ Regression parameters } \\
\cline { 3 - 4 } & & Regression equation & $\mathbf{R}^{\mathbf{2}}$ value \\
\hline Ampicillin & $\left(1-8 \mu \mathrm{g} \cdot \mathrm{ml}^{-1}\right)$ & $y=0.1519 \mathrm{x}+0.0287$ & 0.991 \\
\hline
\end{tabular}

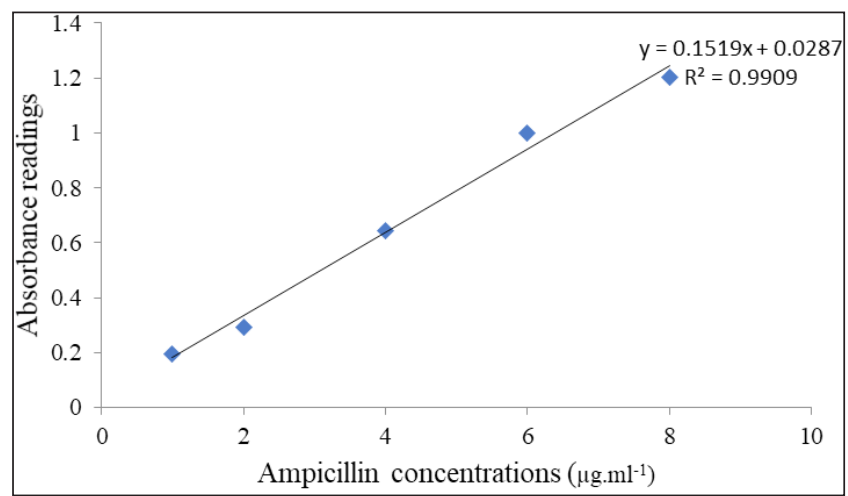

Fig. 1: Calibration curve between ampicillin concentrations against absorbance readings at wavelength $320 \mathrm{~nm}$ wavelength

\section{RESULTS AND DISCUSSION}

In the present study specific UV-Visible spectrophotometric method described by Smith et al. (1967) was used for the determination of ampicillin, based on the copper facilitated formation of the stable acid degradation products, for which the presence of the intact antibiotic molecule is essential. The method was found to be simple, accurate, economical and reproducible. The drug concentrations were found to be linear in the range of $1-8 \mu \mathrm{g} / \mathrm{ml}$ and the correlation coefficient value of 0.991 indicates that method was linear. 
(

Devi et al.

Table 2: In vitro plasma protein binding and kinetic constant of ampicillin in apparently healthy horses

\begin{tabular}{llllllll}
\hline \multicolumn{7}{c}{ Ampicillin concentration $\left(\boldsymbol{\mu g} . \mathbf{m l}^{-\mathbf{1}}\right)$} \\
\hline Experiment No. & $\mathbf{3 . 1 2}$ & $\mathbf{6 . 2 5}$ & $\mathbf{1 2 . 5}$ & $\mathbf{2 5}$ & $\mathbf{5 0}$ & $\boldsymbol{\beta}_{\mathbf{i}}$ & $\mathbf{K}_{\boldsymbol{\beta}}$ \\
\hline 1 & 12.8 & 12.2 & 14.4 & 12.0 & 12.6 & $0.32 \times 10^{-6}$ & $0.0031 \times 10^{-9}$ \\
2 & 12.2 & 12.4 & 13.6 & 11.4 & 13.8 & $0.38 \times 10^{-6}$ & $0.0034 \times 10^{-9}$ \\
3 & 13.4 & 12.8 & 13.0 & 11.2 & 14.8 & $0.31 \times 10^{-6}$ & $0.0041 \times 10^{-9}$ \\
Mean \pm SEM & $12.8 \pm 0.3$ & $12.4 \pm 0.3$ & $13.6 \pm 0.6$ & $11.5 \pm 0.4$ & $13.7 \pm 0.6$ & $0.34 \times 10^{-6} \pm 0.02 \times 10^{-6}$ & $0.003 \times 10^{-9} \pm 0.0003 \times 10^{-9}$ \\
\hline
\end{tabular}

Over all protein binding (\%) Mean \pm SEM is $12.8 \pm 0.07 \%$

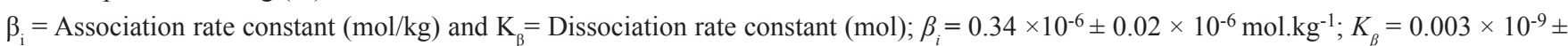
$0.0003 \times 10^{-9} \mathrm{~mol}$.

In-vitro plasma protein binding of ampicillin in the present study was carried out in apparently healthy clinical horses cases by equilibrium dialysis technique. In vitro plasma protein binding and kinetic constants are given in Table 2. The protein bound portion of an antibacterial drug does not have any antimicrobial activity and only free drug in the body possesses pharmacodynamic activity. The extent of protein binding can also directly influence the therapeutic efficacy of antibacterial drug (Craig and Kunin, 1976). The unbound fraction of drug is also desired for distribution and clearance (Wise et al., 1980 and Yamada et al., 1981). The efficacy of $\beta$-lactam antibiotics has direct correlation with the time length for which its unbound concentration remains above minimum inhibitory concentration as percent of dosing interval (Andes and Craig, 2002). So for evaluation of the potential efficacy of ampicillin its plasma proteins binding should be known in horses.

It was reported that ampicillin is slightly plasma protein bound drug $(<25 \%)$ (Ziv and Sulman, 1972). The extent of protein binding percent for ampicillin obtained in the present study was $12.8 \pm 0.07 \%$. However, Durr et al. (1976) reported that ampicillin is very slightly bound to proteins in horses $(6.8-8 \%)$ assayed by equilibrium dialysis technique. $\left(\beta_{\mathrm{i}}\right)$ binding capacity of drug to plasma proteins and $\left(\mathrm{K}_{\beta}\right)$ dissociation rate constant of protein drug complex quantitatively describe the drug protein interaction. In the present study $\left(\beta_{\mathrm{i}}\right)$ and $\left(\mathrm{K}_{\beta}\right)$ of ampicillin were $0.34 \times 10^{-6} \pm$ $0.02 \times 10^{-6}$ mole. $\mathrm{g}^{-1}$ and $0.003 \times 10^{-9} \pm 0.0003 \times 10^{-9}$ mole, respectively. The higher value of $\beta_{i}$ than $K_{\beta}$ indicated that binding of ampicillin to plasma proteins was relatively faster than dissociation of protein drug complex in horses. The plasma samples and buffer were also quantified for the drug levels by using HPLC, and the results were in agreement with the spectrophotometric method.

\section{CONCLUSION}

The advantage of UV-Vis Spectrophotometer application is its quick analysis ability, cost effective and easy to use. The procedure described can be used for routine assay of samples for ampicillin covering a wide potency range. Low plasma protein binding aspect of ampicillin obtained in the present study indicates that as an unbound drug it can easily diffuse into the extra cellular fluid through the capillary pores and attain an almost equal concentration to that in plasma; which can influence its antimicrobial efficacy.

\section{ACKNOWLEDGEMENTS}

Authors are thankful to Guru Angad Dev Veterinary and Animal Sciences University, Ludhiana for providing all the facilities and funding to conduct the research work as part of my $\mathrm{PhD}$ degree.

\section{REFERENCES}

Andes, D. and Craig, W.A. 2002. Animal model pharmacokinetics and pharmaco-dynamics: a critical review. Int. J. Antimicrob. Agents, 19: 261-268.

Askal, H.F., Saleh, G.A. and Omer, N.M. 1991. Utility of certain pi-acceptors for the spectrophotometric determination of some penicillins. Analyst, 116: 387-395.

Baggot, J.D. and Prescott, J.F. 1987. Antimicrobial selection and dosage in the treatment of equine bacterial infections. Equine Vet. J., 19: 92-96. 
Burns, D.T., O'Callaghan, M., Smyth, W.F. and Ayling, C.J. 1991. High-performance liquid chromatographic analysis of ampicillin and cloxacillin and its application to an intramammary veterinary preparation. Fresenius J. Anal. Chem., 340(1): 53-56.

Craig, W.A. and Kunin, C.M. 1976. Significance of serum protein and tissue binding of antimicrobial agents. Annu. Rev. Med., 27: 287-300.

Durr, A. 1976. Comparision of pharmacokinetics of penicillin G and ampicillin in horses. Res. Vet. Sci., 20(1): 24-29

Greenwood, D. 2008. Antimicrobial drugs: chronicle of a twentieth century medical triumph. Oxford University Press, Oxford, UK. p. 124.

Gupta, A., Hammarlund-Udenaes, M., Chatelain, P., Massingham, R. and Jonsson, E.N. 2006. Stereoselective pharmacokinetics of cetirizine in the guinea pig: role of protein binding. Bio pharm. Drug. Dispos., 27(6): 291-297.

Haginaka, J., Junk, W., Hiroyuki, Y., Toyozo, U., Kouichi, T. and Toyoshi, K. 1987. High-performance liquid chromatographic determination of ampicillin and its metabolites in rat plasma, bile and urine by post-column degradation with sodium hypochlorite. J. Chromatogr. B., 400: 101-111.

Hornish, R.E. and Kotarski, S.F. 2002. Cephalosporins in veterinary medicine-ceftiofur use in food animals. Curr. Top. Med. Chem., 2: 717-731.

Meijer, M.C., Van Weeren, P.R. and Rijkenhuizen, A.B.M. 2000. Clinical experiences of treating septic arthritis in the equine by repeated joint lavage: a series of 39 cases. J. Vet. Med., 47: 351-365.
Pilloud, M. 1973. Pharmacokinetics, plasma protein binding and dosage of oxytetracycline in cattle and horse. Res. Vet. Sci., 15(2): 224-230.

Sastry, C.S.P., Rao, S.G., Naidu, P.Y. and Srinivas, K.R. 1998. New spectrophotometric method for the determination of some drugs with iodine and wool fast blue. Talanta, 45: 1227-1235.

Singh, S.K., Sharma, S.K., Sidhu, R.K., Dumka, V.K. and Lamba, J.S. 2019. In-vitro plasma protein binding of marbofloxacin in healthy and disease condition of buffalo calves. J. Anim. Res., 9(1): 75-78.

Smith, J.W.G., De Grey, G.E. and Patel, V.J. 1967. The spectrophotometric determination of ampicillin. Analyst., 92: 247-252.

William, A. and Petri, Jr. 2011. Penicillins, cephalosporins and other $\beta$-lactum antibiotics. In: Laurence Brunton, Bruce Chabner and Bjorn Knollman (eds) 2011. Goodman and Gilman's The pharmacological basis of therapeutics $12^{\text {th }}$ Edn. pp. 1477-1504. McGraw Hill, New York, USA.

Wise, R., Gilette, A.P., Cadge, B., Duncham, S.R. and Baker, S. 1980. The influence of protein binding upon the tissue fluid levels of six beta-lactam antibiotics. J. Infect. Dis., 142: 1782.

Yamada, H., Ichihashi, T., Hirana, K. and Kinoshita, H. 1981. Plasma protein binding and urinary excretion of R- and Sepimers of an aryl malonyl amino 1-oxacephen I in humans. J. Pharm. Sci., 70: 112-113.

Ziv, G. and Sulman, F. G. 1972. Binding of antibiotics to bovine and ovine serum. Antimicrob. Agents. Chemother., 2(3): 206213. 
